\title{
University 4.0 within the context of the sustainable development of higher education
}

\author{
Larisa Gorina $^{1 *}$, Ekaterina Polyakova ${ }^{1}$ \\ ${ }^{1}$ Institute of Engineering and Environmental Security, Togliatti State University, Belorusskaya str. 14, \\ 445020 Togliatti, Russian Federation
}

\begin{abstract}
The process of development of universities from the places where medieval elites met to conduct alliances and partnerships to the modern biotechnological and digital institutions of higher education, research and business took several centuries and went through four main stages. This paper describes the role and the place of the University 4.0 within the context of the sustainable development of higher education in the $21^{\text {st }}$ century. We show that University 4.0 is designed to promote the technology industry through partnerships that support research, marketing, workforce development, as well as entrepreneurship. In keeping with the cooperative nature efforts directed and driven by the policy-makers and relevant stakeholders need to be dedicated to promoting modern universities as hub for the development of intelligent, connected technologies and services that would lead to the sustainable development of higher education that would reflect the challenges of our time.
\end{abstract}

\section{Introduction}

Modern universities face many challenges which creates a necessity for them to establish themselves as local and global leaders. In order to achieve that goal, they should build relationships with both internal and external stakeholders $[1,2]$. In order to build successful relationships, university managers must have a strong understanding of the stakeholders in their institutions and their interests. Today, the leadership skills in the universities can be learned through mentoring and self-development programs offered by organizations specializing in the professional development of university leaders [3, 4]. Moreover, these skills can include understanding mission, vision, goals, values, and morality, transferring behavioural models, and influencing campus culture. The relationship of trust between university stakeholders as well as other interest groups such as lecturers, staff and students are particularly influenced by the perception of the university management [5]. Research on trust-based and integrated approaches and models has shown, key variables that determine successful relationships are influenced in particular by leadership and leadership skills, as well as a strong understanding of the university's mission and goals [6].

Understanding the role of leadership can be particularly important in the context of any university's mission, mission and specific goals. The change in the academy has also changed the ability of university presidents to lead and steer the institution into the future. One can

\footnotetext{
*Corresponding author: gorina@tltsu.ru
} 
rank the six skills presidents must possess when they take office, including vision, vision, and vision for the university, values, ethics, morality, leadership, and behavioural models. For leaders at the top of an institution, these forces can collide in many ways, from a lack of resources and resources to a lack of leadership, or even a combination of both. One can distinguish the University 4.0 management competencies for higher education, which provide university leaders with skills related to managing the resources, resources and resources of a university and management competence [7, 8].

Management skills at universities include relevant management competencies such as planning, budgeting, planning and financing, communication skills and business and leadership skills. Interpersonal skills that are critical to university managers include interpersonal skills such as communication, management skills, and other leadership skills. Relevant stakeholders need to understand what qualities boards should prioritize in interviews and hiring a new president or chancellor.

The American Council on Education (ACE) published a list of the five most important areas occupied by presidents at the time, including reporting to 65 presidents, leading seniorlevel teams, governing-board relationships, and leadership skills. The perception of university presidents describes duties and responsibilities, which include leadership skills such as communication, management skills, interpersonal skills and organizational ability. The American Association of Colleges and Universities (ACU), a national association of more than 1,000 colleges and universities, describes the perception of a college president, including his role as president and the role of the board of trustees $[9,10]$. These might include basic materials, often dealt with in master's and student programs, outlining the basic skills and abilities needed to prepare successfully for the world of work.

Ultimately, there are also individual areas of competence, each of which is a key element within the university's workforce development strategy and the key to successful workplace preparation. One should be aware of her or his abilities so that they have a better understanding of how their lecturer or teacher, class and tasks help them to build the skills that will prepare them to achieve their future professional goals.

It has never been more important to emphasize the generalizable skills in the workplace that university education offers. The key is to recognize and understand the job - related skills that she or he can develop as a university student in the $21^{\text {st }}$ century. Highlighting one's workrelated skills often attracts the attention of potential employers more effectively than high grades or being on top of the class. Thence, university education has gradually transformed through the ages to become more person-oriented and socially-oriented rather than resultoriented.

\section{Evolution of university models over time}

Universities were a form that had its origins historically in Europe, first appeared between the twelfth and thirteenth centuries (University of Paris in France or University of Bologna in Italy being the best examples). In those times, they were ancient centres of higher education, took only one form, and preceded the rise of modern universities such as the universities of Oxford and Cambridge considerably. In medieval Europe, the universities were an important source of education for young men and women of all ages, not just for the elite. They also played an important role in promoting a new generation of leaders and in developing a well-educated citizen $[11,12]$. The history of universities is very different, however, and there are a number of historians who sometimes refer to this form of higher education as a university for convenience. There is undoubtedly a real connection that would justify linking medieval universities in the West with modern universities such as Humboldt University, University of Oxford and University of Cambridge, but the institutional reality is very different. These institutions were initially relatively narrow and have only recently 
spread. But on closer inspection it becomes clear that, despite what has been said on this subject, there was no real connection between the medieval and modern universities in Europe. Early records from Egypt and Mesopotamia suggest that these early institutions operated a university and taught students much as they do today. The Ashurbanipal Library in Nineveh and the Library of Sippar were collections of knowledge that probably also brought students and teachers with them, who taught people who learned complex written languages of their time and began to study and apply their knowledge. These scholars probably taught and were associated with educational institutions, but they did not necessarily conduct research in the same way as modern universities like Oxford or Cambridge [13].

Table 1 that follows describes the evolution of universities (according to their format) from the University 1.0 in the Middle Ages distinguished by the focus on four basic disciplines and finding a way into the societal hierarchy to University 4.0 of today that is marked by the digital surge in research and education.

Table 1. Evolution of universities in different format from the Middle Ages until nowadays [14]

\begin{tabular}{|c|c|c|c|}
\hline University format & Time range & Description & Competences \\
\hline $\begin{array}{c}\text { University 1.0: } \\
\text { Medieval university }\end{array}$ & $\begin{array}{c}\text { Middle Ages }-18^{\text {th }} \\
\text { century }\end{array}$ & $\begin{array}{c}\text { Fundamental } \\
\text { knowledge with an } \\
\text { emphasis on medicine, } \\
\text { theology, law and } \\
\text { astronomy }\end{array}$ & $\begin{array}{c}\text { General knowledge } \\
\text { and competences. } \\
\text { Belonging to certain } \\
\text { classes and elites. }\end{array}$ \\
\hline $\begin{array}{c}\text { University 2.0: } \\
\text { research university }\end{array}$ & $19^{\text {th }}$ century $-1960 \mathrm{~s}$ & $\begin{array}{c}\text { Academic knowledge } \\
\text { (the so-called } \\
\text { "Humboldt } \\
\text { university") }\end{array}$ & $\begin{array}{c}\text { Rational and } \\
\text { deductive thinking, } \\
\text { research and } \\
\text { experimenting }\end{array}$ \\
\hline $\begin{array}{c}\text { University 3.0: } \\
\text { entrepreneurial } \\
\text { university }\end{array}$ & $1970 \mathrm{~s}-2000 \mathrm{~s}$ & $\begin{array}{c}\text { Combining education, } \\
\text { research and business }\end{array}$ & $\begin{array}{c}\text { Providing ideas, } \\
\text { technology and } \\
\text { capital }\end{array}$ \\
\hline $\begin{array}{c}\text { University 4.0: } \\
\text { digital and } \\
\text { biotechnological } \\
\text { university }\end{array}$ & 2010s-now & $\begin{array}{c}\text { Multivariate } \\
\text { knowledge with the } \\
\text { emphasis on ICT and } \\
\text { biotech }\end{array}$ & $\begin{array}{c}\text { Creativity and global } \\
\text { competences }\end{array}$ \\
\hline
\end{tabular}

Academics at universities have been accused of following their old sources, ignoring the needs of modern society, such as the need for education in the arts and sciences. Despite these social changes, which increased the number of educated men filling positions in commerce and administration, universities survived and prospered, and had a monopoly on higher education. Colleges are an important part of the history of modern society, from the Middle Ages to modern times $[15,16]$. Universities were originally founded as a means of promoting a new generation of leaders, and were based on the same principles as schools, such as education in the arts and sciences, as practised in modern universities.

The subjects we are now dealing with are different from those of the medieval universities, but the main purpose and objectives remain the same. In this particular place a whole range of teachers and scholars in higher education taught and received. Together with the entities of society, these persons were associated with the power and privileges that they recognized and with their recognized privileges. Modern universities also pursue these goals but their mission and their focus has shifted and the major factor in this is information and communication technologies and the Internet. 


\section{Universities as leaders in high-tech industry}

Modern universities are keen in striking partnerships with the leaders in high-tech industry. In many countries, a business and university partnerships create a unique symbiosis that is crucial for socio-economic development $[17,18]$. One reason Canada is a world leader in knowledge-based industries is its integrated approach to fostering economic growth through innovation. Canada provides the world's largest number of high-tech research and development centres, and is also aggressively supporting the development of the country's high-tech industries, such as robotics, artificial intelligence (AI), and machine learning [19].

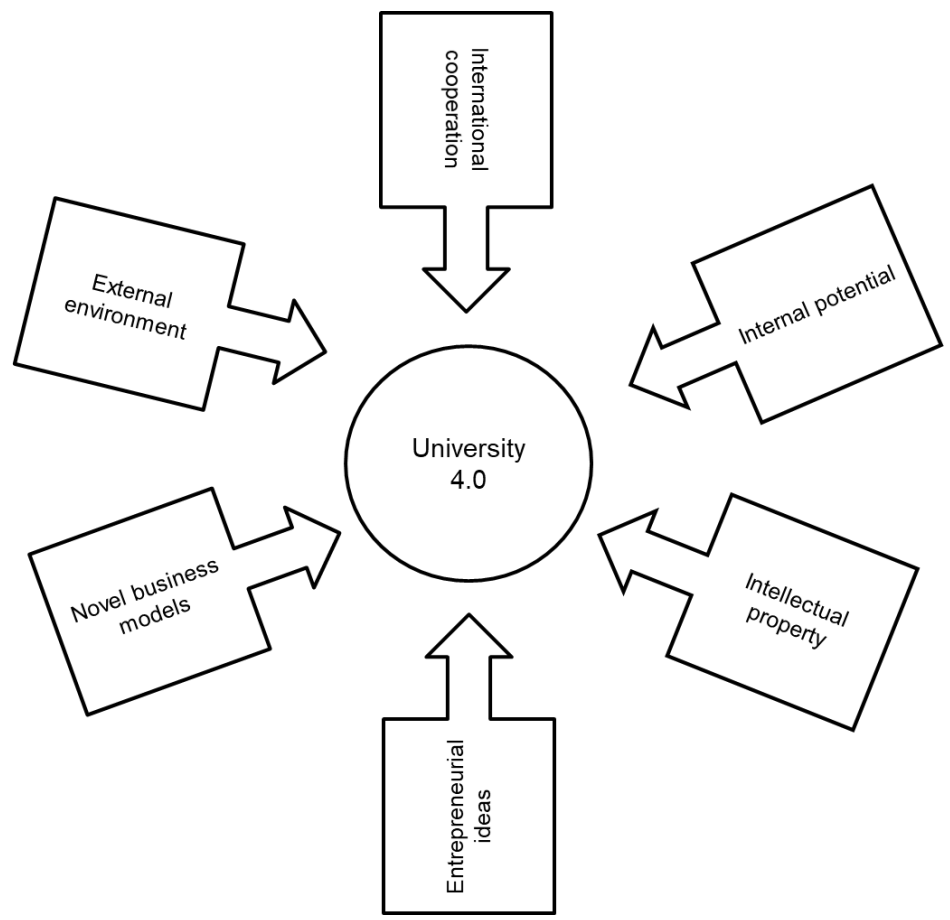

Fig. 1. Format of University 4.0 on the new technological market

Figure 1 above describes the current format of University 4.0 which operates on the new technological markets. Here, the importance of information and communication technologies (ICT) becomes apparent. Some regions such as Hawaii leverages its unique geographical factors to develop skills and businesses that have the potential to become world-class and dominate the development of high-tech industries such as robotics, artificial intelligence (AI), and machine learning. Here, the partnership with the universities and research centres is very important. For example, the University of Hawaii cluster shares common features with the island of Oahu, home to Hawaii Island, the largest island in the United States, and is a major hub for research, development, and production of advanced technologies and services.

American leaders such as President Obama made expanding the ability of United States workers to improve their skills, foster innovation, and improve manufacturing competitiveness a priority. United States' system of community colleges currently enrols more than 7 million students, more than 1.5 million of whom are studying in high-tech industries [20,21]. By modernizing technological and technical higher education at modern universities, it is creating a University 4.0. This type of university makes a stress on 
developing students' abilities in the field of improved academic skills, including science, technology, engineering, and mathematics (all known as STEM).

In general terms, ICT uses a wide range of partners from government, industry and academia to link higher education directly to the needs of the private sector. In addition, ICT strengthens students' ability to acquire technical and English skills and focuses on technical and technical training for women through leadership forums, academic initiatives and scholarships.

Universities of the $21^{\text {st }}$ century need to build strategic leadership capabilities to help their leaders to promote university autonomy, improve the quality of courses, and build lasting partnerships with the private sector. This will enable the multigovernmental team to develop a durable and sustainable curriculum for e-learning that will help to close the skills gap and improve access to high-tech jobs in the automotive, aerospace and technical industries. For example, Indian River State College is proud to partner with the University of South Florida and the Office of Science and Technology Policy and Development (OSTD) of the U.S. Department of Education in developing virtual reality educational tools and training to support automotive and aerospace education [22]. ICT's commitment to developing and evaluating the widespread use of digital learning tools will strengthen the science, technology, engineering, and mathematics (STEM) talent pipeline, foster diversity among diverse populations, and ultimately provide unique opportunities that have never been available to students and faculty in STEM subjects such as computer science, engineering, and math.

\section{Transition of talent and knowledge in modern higher education}

What skills can an organisation expect from its students, faculty, staff and students in the future in the age of modern higher education? Higher education is well known in many ways, but it is not as rigorous as it used to be, largely because of a lack of investment in human capital in the education system. Employers need technology - improved learning to prepare for hiring, and education for the future. If we consider education, especially higher education, as something that everyone should have access to, rather than being informed solely through an investment approach, "human capital" should be considered the most appropriate tool to explain the benefits that individuals and society can derive from education.

Many experts believe change is necessary and urgent because the current system is anachronistic - in other words, it is still entrenched in the last century and has failed to meet the needs of the digital age. One would probably agree with the idea that certificates and diplomas are a means of applying knowledge of the labour market and takes the form of tacit criteria set by the ruling class in order to identify people with special social origins. Although not invalid, it disregards human capital theory and remains concerned that it has become the property of the ruling classes and is being used as a mechanism for maintaining power and tacitly reproducing social inequality [23, 24].

With regard to the above, one question comes to mind: how disruptive innovation is changing the way the world learns and explains that the current form of teaching cannot provide today's students with the skills they need to interact with a digital society. Education must be about empowering pupils with transferable skills and holding them accountable for their abilities in a rapidly changing world, making them more accountable than those who do not prescribe content selected for its relevance or relevance in the past. One of the most prominent figures in education, Dr. Martin Luther King Jr., has repeatedly pointed out that the education system cannot change its curriculum, or even change one iota objectively, because of the enormous changes in the economy, culture, and personnel over the last 50 years [25]. This can often mean being open to the possibilities presented, rather than trying to teach or prescribe the use of certain programs. 
Although digital integration is also essential for thorough education in the $21^{\text {st }}$ century, it is not simply a matter of supplementing existing teaching methods with technology. Students are increasingly advanced users of technology, whether they are first-time school-goers or not. Classroom technology classes astonish children by trying to teach them programs, websites, and hardware that are no longer relevant, but that they understand much better than the teacher. This new form of learning relies heavily on machines, with machine tutors using data and tracking student progress to recursively improve the quality of knowledge and student support. This requires new teaching techniques, facilitated by technology, such as "turning the classroom around" and "including learning". In order to maintain and advance humanistic education, which is important for its ability to deal with ethical and value issues raised by social change, institutions must respond to the needs of a new generation of students, students of colour, women and people with disabilities, all of whom demand access to quality education and support and to the education of their children. A number of information-based industries are being transformed or threatened, with new entrants offering specialised services that are separate from bundled services such as online education, social media and social networks. However, companies that want to use this capacity are constrained by their ability to stay up to date and recruit the talent they need. This can be achieved through training programmes that enable employers to play a more active role in managing their talent needs and to build a culture of continuous learning and innovation. Apprenticeships offer long-term, paid, work-oriented learning opportunities and structured curricula that ensure not only what you earn, but also how you are educated and in which industries you use it. Apprenticeship registration is one of the first steps towards formal authorisation of the use of apprenticeships as part of an employer-employee relationship in our education system.

Learning outcomes, measured not by course points but by students' skills, should be the benchmark of quality that makes the most sense to consumers. It also calls into question the validity of the current system, which certifies that a student has achieved certain necessary skills, regardless of where those skills were acquired. Technology is shaping the new educational environment and the role of technology in the future of higher education and higher education is also being called into question. In a free education system stimulated by technological progress in the late twentieth century, the idea of a way to document educational achievements was unthinkable. But in a digital knowledge society, where the economy is dominated by the use of technologies such as the Internet, social media, and mobile phones, it is now possible.

\section{Conclusions}

$\mathrm{Al}$ in all, we can see that higher education in general and universities in particular have come a long way that lasted for centuries. Their path has been market, and fostered, by the advancements in science and progress and can be traced to the needs of the society in their respective periods of existence.

University 4.0 that we have today represents the new type of the university that can exist within context of the sustainable development of higher education. It is distinguished by the high penetration of ICTs and relevant technologies. In the same time, it is more problemoriented with the goal of analysing and solving global issues. In addition, University 4.0 is also product-oriented with a focus on delivering a viable product. Finally, it is also sociallyoriented with the aim of tackling and solving the problems of the society and helping to maintain the balance in the ecosystem of this society.

The new type of the university is modern and competitive but it also centred around the personal needs and goals of its students. In its development on the path of transforming the whole concept of higher education, University 4.0 will effectively absorb the new 
components of the economic and social development of the future as well as the global environmental and sustainability challenges our society faces today.

\section{References}

1. W. Leal Filho, E. Pallant, A. Enete, B. Richter, L.L. Brandli, International Journal of Sustainable Development \& World Ecology, 25(8), 713-721 (2018)

2. M. Klofsten, A. Fayolle, M. Guerrero, S. Mian, D. Urbano, M. Wright, Technological Forecasting and Social Change, 141, 149-158 (2019)

3. E. Lekashvili, Marketing and Management of Innovations, 1, 281-293 (2019)

4. K. Guthrie, D. Jenkins, The role of leadership educators: Transforming learning (2018)

5. A. Lafuente-Ruiz-de-Sabando, P. Zorrilla, J. Forcada, European Research on Management and Business Economics, 24(1), 8-16 (2018)

6. M. Sánchez-Barrioluengo, P. Benneworth, Technological forecasting and social change, 141, 206-218 (2019)

7. M. Hernandez-de-Menendez, C.A.E. Díaz, R. Morales-Menendez, International Journal on Interactive Design and Manufacturing (IJIDeM), 14(3), 789-803 (2020)

8. E. Lisá, K. Hennelová, D. Newman, International Journal of Work-Integrated Learning, 20(1), 71-82 (2019)

9. ACEACPS, https://www.aceacps.org/duties-responsibilities-dashboard (2021)

10. M.J. Zeig, R.G. Baldwin, K.M. Philanthropy \& Education, 2(1), 53-74 (2018)

11. H. De Ridder-Symoens, W. Rüegg (eds.), A history of the university in Europe (2003)

12. R. Nureev, V. Volchik, W. Strielkowski, Social Sciences, 9(5), 79 (2020)

13. J. Curtis (ed.), Studies in Ancient Persia and the Achaemenid Period (2020)

14. W. Strielkowski, J. Wang, $6^{\text {th }}$ International Conference on Social, economic, and academic leadership (ICSEAL-6-2019), 1-4 (2020)

15. H. Ostrowicka, Ł. Stankiewicz, Higher Education Research \& Development, 38(3), 609622 (2019)

16. A. Hoffman, The engaged scholar: Expanding the impact of academic research in today's world (2021)

17. Y. Xing, Y. Liu, S.C.L. Cooper, British Journal of Management, 29(4), 670-690 (2018)

18. P. Jackson, R.K. Mavi, Y. Suseno, C. Standing, Science and Public Policy, 45(4), 553564 (2018)

19. M. Plaza, I. David, F. Shirazi, International Journal of Production Economics, 205, 215227 (2018)

20. NCES, https://nces.ed.gov/programs/coe/indicator_cha.asp (2021)

21. B. Obama (ed.), Strategy for American innovation: Driving towards sustainable growth and quality jobs (2011)

22. D. Dykes, http://www.greenvillebusinessmag.com/2020/10/05/331217/preparing-thenext-generation-of-technological-talent-in-advanced-manufacturing (2020)

23. T. Kromydas, Palgrave communications, 3(1), 1-12 (2017)

24. R. Grundmann, Minerva, 55(1), 25-48 (2017)

25. The Seattle Times, https://projects.seattletimes.com/mlk/words-education.html (2017) 